\title{
UTVIKLINGEN AV STRAFFERETTSLIGE REAKSJONER I NORGE DE SENERE ÅRENE
}

AV HØYESTERETTSDOMMER, DR.JUR. MAGNUS MATNINGSDAL

In recent years, there has been political pressure to increase the level of punishment in Norway - especially in regard to crimes of violence and sex, and those concerning extensive and repeated property crime. Several legislative amendments have been passed with this in mind. The consequences of these amendments have been harder sentences and an increasing number of inmates. At the same time, it has been emphasized that these more punitive sentences should be applied specifically to the more aggravated crimes. Alternative custodial reactions have therefore been developed for use in less serious cases, including community punishment. Community punishment, which replaced community service in 2002, provides a completely different set of possibilities for adjusting penal sanctions to specific convicted offenders. Moreover, during the last few years, the trial system has introduced suspended sentences for drunken drivers with alcohol problems who would otherwise receive sentences of imprisonment. Those given a suspended sentence are expected to attend an educational program and are put in contact with treatment authorities. The decision to grant a conditional sentence/community punishment to those who would otherwise qualify for imprisonment is heavily influenced by whether the offender is considered to be in a period of rehabilitation.

\section{Generelt - særlig om utviklingen mot et strengere straffenivå}

Den kriminalpolitiske debatten i Norge har i mange år gjennomgående vært dominert av et politisk ønske om et strengere - til dels atskillig strengere - straffenivå, særlig for volds- og seksualforbrytelsene samt for omfattende og gjentatt vinningskriminalitet. Politisk uenighet om endring i straffenivået har primært relatert seg til hvor mye straffen bør skjerpes, og mindre til spørsmålet om den bør skjerpes. Ved de ulike lovendringene synes allmennpreventive hensyn å ha dominert i noen tilfeller, mens hensynet til proporsjonalitet synes å ha vært mest fremtredende ved andre lovendringer. ${ }^{1}$ Men som jeg kommer tilbake til, har det også blitt utviklet nye reaksjoner i frihet som alternativ til fengselsstraffen.

\footnotetext{
* Title in English: Recent Developments in Penal Sanctions in Norway. Original in Norwegian.

${ }^{1}$ Se Matningsdal og Strandbakken i Flores juris et legum, Festskrift til Nils Jareborg, 2002 s. 483-491.
} 
Ønsket om å redusere "kvantumsrabatten" ved omfattende kriminalitet førte til at strl. § 62 om straffutmåling ved konkurrens ble endret ved lov av 10. januar $2003 \mathrm{nr}$. 2 slik at straffen nå kan utmåles til inntil "det dobbelte av den høyeste straff som for noen av dem er bestemt". Tidligere økte strafferammen med inntil $50 \%$.

Videre ble strl. $\S 61$ om gjentakelse endret ved lov av 4. juli 2003 nr. 78. Bestemmelsen gir nå en generell hjemmel for skjerping av strafferammen dersom vedkommende innen nærmere bestemte frister etter at straffen er helt eller delvis fullbyrdet (seks år ved forbrytelse, to år ved forseelse) på ny begår en ny straffbar handling av "samme art". I så fall forhøyes strafferammen til det dobbelte. Ved denne lovendringen tok man sikte på å innføre et opplegg med double jeopardy ved at straffskjerpingen primært skal gi seg utslag i en betinget del som kommer i tillegg til den ubetingede straffen som utmåles. Ved at vedkommende etter løslatelsen risikerer også å måtte sone den betingede delen dersom det begås nye straffbare handlinger, håper man å motvirke videre kriminalitet. ${ }^{2}$

Når man studerer utviklingen i Norge, er det viktig å være oppmerksom på at loven tradisjonelt har stilt retten svært fritt ved straffutmålingen. Straffeloven inneholder ikke generelle prinsipper om straffutmåling eller reaksjonsvalg. Derimot finnes det enkelte spesielle bestemmelser - f.eks. strl. § 27 om utmåling av bot. ${ }^{3}$ I forbindelse med den pågående revisjonen av straffeloven foreslås den gjeldende ordningen videreført. ${ }^{4}$

Loven inneholder videre gjennomgående vide strafferammer. Som eksempel nevnes at et innbruddstyveri nærmest unntaksfritt regnes som grovt tyveri og kan straffes med bøter eller fengsel inntil seks år, jf. strl. § 258. Når da loven ikke gir nærmere retningslinjer for straffutmålingen, kan domstolene på nærmest fritt grunnlag utvikle straffenivået. Høyesterett har spilt en sentral rolle i denne sammenheng. Fram til 1. august 1995 ble anker over herreds- eller byrettens straffutmåling, saksbehandling eller lovanvendelse alltid fremmet direkte for Høyesterett. Det samme gjaldt for de alvorligste straffesakene som i første instans ble behandlet av lagmannsretten. Høyesterett avsa dermed et så stort antall dommer om straffutmåling at denne praksis langt på vei ble detaljstyrende for de underordnede domstoler. ${ }^{5}$ Med virkning fra 1. august 1995 har vi imidlertid innført den såkalte "to-instansreformen" som innebærer at samtlige straffesaker først behandles av tingretten, og at lagmannsrettene er gjort til ankeinstans. Dermed får Høyesterett færre ankesaker til behandling. Men Høyesterett har fortsatt ambisjoner om å spille en ledende rolle ved utviklingen av strafferetten, og behandler stadig et betydelig antall straffesaker. I 2003 avgjorde Høyesterett totalt 100 straffesaker. I de fleste av disse sakene ble straffutmålingen behandlet.

\footnotetext{
${ }^{2}$ Se Ot.prp. nr. 62 (2002-2003) s. 73-86 og 94-95.

${ }^{3}$ I Rettsteori og rettsliv, Festskrift til Carsten Smith, 2002, s. 570-571 har jeg gitt en kortfattet oversikt over disse bestemmelsene.

${ }^{4}$ Jf. NOU 1983: 57 s. 241-242, NOU 1992: 23 s. 209-210 og NOU 2002: 4 s. 144.

${ }^{5}$ Om Høyesteretts rolle ved utviklingen av strafferetten kan det bl.a. vises til Røstad, Innkast i straffefeltet, 1993 s. 423-431 og Matningsdal i Tidsskrift for strafferett 2002 s. 345-359.
} 
Når det har vært et sterkt politisk ønske om å skjerpe straffenivået, har det sentrale spørsmålet vært hvilken fremgangsmåte Stortinget må velge for å påvirke Høyesteretts, og dermed de underordnede domstolers, straffutmåling. Нøyesterett har av flere grunner vært negativ til å legge vekt på utsagn utenom lovgiverrollen. ${ }^{6} \mathrm{Og}$ uten lovendring har Høyesterett vært forsiktig med å foreta markerte endringer i straffenivået. ${ }^{7}$ Dette har tvunget Stortinget til å foreta lovendringer for å oppnå sitt mål om strengere straffenivå - normalt ved at man har skjerpet strafferammen i det aktuelle straffebudet og kombinert dette med utsagn i samme retning i forarbeidene. Slike endringer har Høyesterett fulgt opp. ${ }^{8}$ Men Stortinget har også gått lenger ved at det ved lov av 11. august $2000 \mathrm{nr}$. 76 forhøyet minstestraffen for voldtekt til samleie og samleie med barn under 14 år fra fengsel i ett til fengsel i to år, jf. strl. §§ 192 og 195. Samtidig ble definisjonen av voldtekt utvidet - bl.a. ved at samleie med en sovende kvinne nå regnes som voldtekt og omfattes av minstestraffen. ${ }^{9}$ Denne lovendringen har ført til et markert strengere straffenivå for voldtekt til samleie. Normalstraffen for en ordinær voldtekt til samleie kan i dag anslås til fengsel i ca. to år og ni måneder ${ }^{10}-$ noe som innebærer en straffskjerping på nærmere ett år. Også for voldsforbrytelsene har straffenivået $\emptyset \mathrm{kt}$ de senere årene. For et ordinært forsettlig drap har f.eks. gjennomsnittsstraffen økt fra fengsel i ca. åtte år på 1980-tallet til nærmere ti år i dag.

Men vi har også eksempler på endringer i motsatt retning. For det første har det strenge norske straffenivået for narkotikaforbrytelser blitt noe modifisert de senere årene. Dette gjelder ikke minst ved erverv av mindre kvanta til eget bruk. ${ }^{11}$ Dessuten ble straffereaksjonene ved promillekjøring kraftig endret i 1988. Mens man tidligere som hovedregel anvendte ubetinget fengsel i 21 dager, eller noen få ytterligere dager, straks alkoholkonsentrasjonen oversteg 0,5 promille, anvendes det nå omtrent aldri ubetinget fengsel ved førstegangsovertredelse med alkoholkonsentrasjon under 1,0 promille. Det er først ved alkoholkon-

\footnotetext{
${ }^{6}$ Jf. Matningsdal i Tidsskrift for strafferett 2002 s. 345-359 på s. 356-359.

${ }^{7}$ Jf. bl.a. prinsipputtalelsene i Rt. 1994 s. 552 og 1999 s. 363 om endringer i straffenivået ved voldtekt.

${ }^{8}$ Jf. Matningsdal i Rettsteori og rettsliv, Festskrift til Carsten Smith, 2002, s. 576-579.

${ }^{9}$ Den strengeste straffen Høyesterett har utmålt for denne forbrytelsen før forholdet ble definert som samleie, når ikke forbryteren selv hadde hensatt kvinnen i bevisstløs tilstand, er fengsel i 120 dager, jf. Rt. 2000 s. 800 . Noen måneder senere ble minstestraffen seksdoblet! Ved Høyesteretts kjennelse av 14. januar 2004 i sak HR-2004-00078-A ble straffen for et slikt tilfelle satt til ubetinget fengsel i to år og seks måneder.

${ }^{10}$ I Rt. 2003 s. 1248 ble straffen satt til fengsel i to år og åtte måneder for en voldtekt som det ikke knyttet seg spesielle skjerpende omstendigheter til.

${ }^{11}$ Se særlig Rt. 1999 s. 33.
} 
sentrasjoner over 1,5 promille at lovens utgangspunkt er at det skal anvendes ubetinget fengsel, jf. vegtrafikkloven $\S 31$ annet ledd. ${ }^{12}$

Resultatet av denne utviklingen kan måles i fangetallet. Det påvirkes av to faktorer - dels det totale antall lovbrudd som kvalifiserer for ubetinget fengsel, og dels av hvor strenge straffer som utmåles. Selv om det i dag ikke - eller i alle fall i liten utstrekning - anvendes ubetinget fengsel ved enkelte overtredelser hvor dette tidligere var vanlig, er fangebefolkningen $\varnothing$ kende. Fangetallet utgjorde i 199856 pr. 100.000 innbyggere. ${ }^{13}$ I 2002 hadde Norge på årsbasis i gjennomsnitt 2.736 innsatte, hvorav varetektsinnsatte utgjorde 648 . Fordelt på et innbyggertall på ca. 4,5 millioner personer gir dette nesten 61 personer pr. 100.000 innbyggere. I 2003 utgjorde det gjennomsnittlige belegget 2.850 personer. Dette gir nesten 63 personer pr. 100.000 innbyggere. I tillegg til det totale fangetallet må det tas i betraktning at mens vi i 2000 ikke hadde soningsk $\varnothing,{ }^{14}$ har vi deretter gradvis bygget opp en soningsk $\varnothing$ som ved årsskiftet 2003/2004 tilsvarte et fengsel med 541 plasser med fullt belegg hele året. Dersom det gjennomsnittlige belegget for 2002 og 2003 tilføres 1/3 hver av disse domfelte, ville det ha gitt et fangetall på ca. 65 og 67 personer pr. 100.000 innbyggere de aktuelle årene.

\section{Strafferettslige særreaksjoner for farlige lovbrytere}

For farlige lovbrytere hadde vi inntil 2002 hjemmel for å anvende sikring som var regulert i strl. § 39. Denne reaksjonen var den eneste aktuelle for utilregnelige lovbrytere. For tilregnelige lovbrytere kom den i tillegg til fengselsstraffen. Sikring var en tidsubestemt reaksjon. Det ble fastsatt en lengstetid som senere kunne forlenges.

Med virkning fra 1. januar 2002 har sikring blitt erstattet av tre nye særreaksjoner. For personer som er utilregnelige fordi de var psykotisk eller bevisstløs i gjerningsøyeblikket, strl. § 44 første ledd, gir $\S 39$ hjemmel for dom på overføring til tvungent psykisk helsevern". Reaksjonen forutsetter at det "anses nødvendig for å verne samfunnet" og at "[1]ovbryteren har begått eller fors $\varnothing \mathrm{kt}$ å begå en alvorlig voldsforbrytelse, seksualforbrytelse, frihetsberøvelse, ildspåsettelse eller en annen alvorlig forbrytelse som krenket andres liv, helse eller frihet, eller kunne utsette disse rettsgodene for fare. I tillegg må det antas å være en nærliggende fare for at lovbryteren på nytt vil begå en alvorlig forbrytelse som krenker eller utsetter for fare andres liv, helse eller frihet". Farekravet innebærer at det kreves en kvalifisert gjentakelsesfare. Ved gjentakelse inneholder strl. § 39

\footnotetext{
${ }^{12}$ Utmålingspraksis ved promillekjøring er inngående behandlet av Matningsdal i Torgersen og Engstrom, Vegtrafikkloven og trafikkreglene, tredje utgave, 1998, s. 425-454.

${ }_{13}^{13}$ Jf. Christie, Kriminalitetskontroll som industri, tredje utgave, 2000, s. 25.

${ }^{14}$ Soningskøen omfatter domfelte som har ventet mer enn 60 dager på soning etter rettskraftig dom.
} 
nr. 2 noe andre vilkår for å anvende reaksjonen. ${ }^{15}$ Retten fastsetter ingen lengstetid for hvor lenge vedkommende kan være undergitt tvungent psykisk helsevern. Rettsstillingen reguleres av psykisk helsevernloven av 2. juli 1999 nr. 62 kapittel 5. Etter strl. § 39 b kan det kreves opphør av reaksjonen dersom det ikke lenger foreligger tilstrekkelig gjentakelsesfare.

For personer som er utilregnelige pga. psykisk utviklingshemning, strl. § 44 annet ledd, gir strl. § 39 a hjemmel for å anvende tvungen omsorg i en fagenhet innenfor spesialisthelsetjenesten som er innrettet for formålet. Vilkårene for å anvende denne reaksjonen er de samme som for dom på tvungent psykisk helsevern. Heller ikke ved denne reaksjonen fastsettes det noen lengstetid, men den kan kreves brakt til opphør når det ikke lenger foreligger tilstrekkelig gjentakelsesfare, jf. strl. § 39 b.

For tilregnelige, farlige lovbrytere, kan det anvendes forvaring etter strl. $\S$ $39 \mathrm{c}-39 \mathrm{~h}$. Grunnvilkåret er omtrent det samme som for dom på tvungent psykisk helsevern. I motsetning til sikring idømmes forvaring i stedet for ubetinget fengsel. Det fastsettes en tidsramme som i praksis normalt er ubetydelig lenger enn den fengselsstraffen som ellers ville ha blitt utmålt. ${ }^{16}$ Videre fastsettes det normalt en minstetid som tilsvarer ca. 2/3 av den fengselsstraffen som ellers ville ha blitt utmålt. Prøveløslatelse er utelukket før utløpet av minstetiden. Tidsrammen kan senere forlenges. Pr. 11. februar 2004 sonet 39 personer dom på forvaring.

\section{Ny straffegjennomføringslov}

Fullbyrding av fengselsstraff var tidligere regulert i lov om fengselsvesenet av 12. desember $1958 \mathrm{nr}$. 7. Med virkning fra 1. mars 2002 ble denne loven erstattet av straffegjennomføringsloven av 18. mai $2001 \mathrm{nr} .21$.

Etter denne lovens $§ 10$ skal fengselsstraff enten gjennomføres i fengsel med "høyt sikkerhetsnivå" (lukket fengsel), fengsel med "lavere sikkerhetsnivå" (åpent fengsel) i "overgangsbolig" eller utenfor fengsel med særlige vilkår. Avdeling i fengsel med "høyt sikkerhetsnivå" kan innrettes med "særlig høyt sikkerhetsnivå".

Fullbyrdingen starter som utgangspunkt i fengsel med "høyt sikkerhetsnivå", jf. lovens $\S 11$ første ledd. Dersom straffen ikke overskrider fengsel i to år, skal kriminalomsorgen vurdere om den domfelte kan settes direkte inn i fengsel med "lavere sikkerhetsnivå" - dvs. åpent fengsel, jf. lovens § 11 fjerde ledd. I "særlige tilfeller" kan dette skje selv om dommen er strengere enn fengsel i to år.

Under soningen åpner lovens $\S 15$ en viss adgang til å overføre den domfelte til mindre restriktivt fengsel. Er vedkommende ikke innsatt i lukket fengsel, kan

\footnotetext{
${ }^{15}$ Reaksjonen er behandlet i Rt. 2002 s. 744, 2002 s. 990 og 2003 s. 1085.

${ }^{16}$ Om prinsippene for fastsetting av denne tidsrammen kan det særlig vises til Rt. 2002 s. 1667.
} 
det også skje overføring til overgangsbolig. Forutsetningen er at "formålet med straffen eller sikkerhetsmessige grunner [ikke] taler mot, eller at det er grunn til å anta at innsatte vil unndra seg gjennomføringen". Overføringen må dessuten være "hensiktsmessig for å fremme en positiv utvikling og for å motvirke ny kriminalitet".

Lovens $\S 16$ åpner videre en viss adgang til å gjennomføre deler av straffen utenfor fengsel når halvdelen av straffetiden er gjennomført. Slik soning må være "nødvendig og hensiktsmessig for å sikre en fortsatt særlig positiv utvikling og motvirke ny kriminalitet". Vedkommende må ha fast bopel og være sysselsatt i form av arbeid, opplæring eller andre tiltak. Den domfelte må videre unnlate å bruke rusmidler, bedøvelsesmidler, hormonpreparater eller andre kjemiske stoffer som ikke er lovlig foreskrevet. Det kan også oppstilles ytterligere vilkår f.eks. å delta i program eller å innta antabus eller andre foreskrevne medikamenter. Er det "sannsynlig at domfelte har begått eller vil begå en straffbar handling, unndra seg gjennomføringen eller bryte forutsetninger og vilkår for gjennomf $\varnothing$ ring av straff utenfor fengsel", kan vedkommende tilbakeføres til fengsel.

Etter lovens $\S \S 12$ og 13 kan fengselsstraff også gjennomføres i institusjon eller på sykehus. Soning i institusjon er særlig aktuelt for enkelte rusmisbrukere.

Fram til slutten av 1990-tallet skjedde prøveløslatelse nærmest unntaksfritt når den domfelte hadde sont $2 / 3$ av straffen. Dette møtte etter hvert stor politisk misnøye, og praksis ble lagt noe om. Straffegjennomføringsloven $\S 42$ fastsetter at prøveløslatelse fortsatt som hovedregel kan skje når den domfelte har sont $2 / 3$ av straffen, men prøveløslatelse skal ikke skje "hvis omstendighetene etter en totalvurdering gjør løslatelse utilrådelig. Kriminalomsorgen skal særlig legge vekt på domfeltes atferd under gjennomføring av straffen, og om det er grunn til å anta at domfelte vil begå nye straffbare handlinger i prøvetiden." Selv om de fleste domfelte fortsatt prøveløslates etter å ha sont $2 / 3$ av straffen, er det ikke lenger nærmest en selvfølge at man prøveløslates på dette tidspunktet.

Prøvetiden tilsvarer resttiden, og etter $\S 43$ kan det settes flere forskjellige særvilkår ved prøveløslatelsen.

Kriminalomsorgen plikter å forberede løslatelsen. Etter § 41 skal den ”i god tid forberede og bidra til at forholdene legges til rette for prøveløslatelse. Dette gjelder så langt mulig også overfor innsatte som gjennomfører kortere fengselsstraff. Det skal i nødvendig utstrekning tas kontakt med offentlige myndigheter, organisasjoner eller privatpersoner som kan yte bistand for å oppnå ordnede boligforhold, arbeid, opplæring eller andre tiltak som kan bidra til en lovlydig livsførsel etter løslatelse." 


\section{Anvendelse av betinget dom}

Fremstillingen under I viser at hovedtendensen har gått i retning av strengere reaksjoner - særlig ved alvorlige eller omfattende volds-, sedelighets- og vinningsforbrytelser. Dette har gitt en økt fangebefolkning, og man har ikke helt maktet å følge opp med å etablere et tilstrekkelig antall soningsplasser.

Denne tendensen er imidlertid ikke enerådende. Som nevnt har straffeloven stort sett overlatt utviklingen av hvilke straffutmålingsmomenter som er relevante, og hvilken vekt de skal ha, til domstolene med Høyesterett i spissen.

I vår sammenheng er det særlig naturlig å fremheve utviklingen av rehabiliteringsmomentet som moment ved valget mellom ubetinget fengsel og reaksjoner i frihet. Selv om momentet også ble vektlagt før 1980, har denne utviklingen skutt betydelig fart etter 1980, og det finnes en rekke eksempler på at personer med flere fengselsopphold bak seg idømmes betinget fengsel når det er utsikt til bedring i deres livssituasjon. ${ }^{17}$

Rehabiliteringsmomentet har også spilt en sentral rolle ved valget mellom ubetinget fengsel og samfunnstjeneste, ${ }^{18}$ og vil i fremtiden spille en tilsvarende rolle ved samfunnsstraffen som har erstattet samfunnstjenesten, jf. nedenfor. Praksis ved narkotikaforbrytelsene er svært illustrerende. Høyesterett har etter hvert anvendt samfunnstjeneste i en rekke saker om narkotikaforbrytelse. ${ }^{19}$ Ofte har dette momentet vært utslagsgivende.

Rt. 1991 s. 275 er illustrerende. Her var en ustraffet mann idømt ett år betinget fengsel med vilkår om samfunnstjeneste for narkotikaforbrytelser og hjemmebrenning. Selv om det ikke forelå noen rehabiliteringssituasjon, kom mindretallet (to dommere) til at det burde anvendes samfunnstjeneste. Flertallet (tre dommere) kom derimot til at det ikke var grunnlag for samfunnstjeneste. Førstvoterende viste til at i "de få tilfelle hvor Høyesterett har funnet at det bør gis betinget dom på vilkår av samfunnstjeneste overfor en narkotikakriminalitet som i grovhet kan sammenlignes med hva man står overfor i denne sak, har det foreligget rehabiliteringshensyn eller andre sterke personlige hensyn mot å anvende ubetinget fengsel" (s. 279). Avgjørelsen er fulgt opp i Rt. 2000 s. 1446 (dissens 3-2). Se også Rt. 1999 s. 1504.

Det er selvsagt ikke bare rehabiliteringsmomentet som kan begrunne betinget dom. ${ }^{20}$ Betinget dom spiller en sentral rolle innenfor de strafferettslige reaksjonene. I 2002 ble det således totalt anvendt ubetinget fengsel i 7.204 saker, mens det ble anvendt betinget dom i 7.336 saker - herav 5.046 saker hvor det også er ilagt bot. Videre ble straffen gjort delvis betinget i 1.856 saker.

\footnotetext{
${ }^{17}$ Se Matningsdal/Bratholm (red.), Straffeloven med kommentarer, Første Del, 2. utgave 2003, s. 449-450.

${ }^{18}$ Jf. Matningsdal/Bratholm op.cit. særlig s. 122-123.

${ }^{19}$ Jf. Matningsdal/Bratholm op.cit. s. 115-116.

${ }^{20}$ En grundig gjennomgang av de ulike momentene som kan begrunne betinget dom, og praksis ved de enkelte overtredelsene er gitt i Matningsdal/Bratholm op.cit. s. 443-461.
} 


\section{Samfunnsstraff}

I Norge ble det forsommeren 1984 innledet en prøveordning med samfunnstjeneste i Sør-Rogaland. Fors $\emptyset$ ket ble etter hvert utvidet, og fra 1988 var prøveordningen landsomfattende. Erfaringene med prøveordningen var imidlertid så positive at ved lov av 15 . mars $1991 \mathrm{nr}$. 4 ble samfunnstjeneste lovfestet som en egen strafferettslig reaksjon, jf. strl. $\S \S 28$ a -28 c. Antallet dommer $\emptyset$ kte gradvis, og nådde toppunktet i 1994 med 1.026 dommer. Deretter sank antallet gradvis, og nådde bunnivået i 1999 med 546 dommer. Senere har antallet $\varnothing \mathrm{kt}$ noe.

Ved vedtakelsen av straffegjennomføringsloven i 2001 ble samfunnstjenesten erstattet av samfunnsstraffen ${ }^{21}$ som trådte i kraft 1. mars 2002. Denne straffen representerer en videreutvikling av samfunnstjenesten. Mens en dom på samfunnstjeneste innebar at den domfelte skulle utføre et bestemt antall timer ulønnet arbeid, og i tillegg stå under tilsyn av kriminalomsorgen i gjennomføringstiden som normalt tilsvarte den alternative fengselsstraffen, gir straffegjennomf $\varnothing$ ringsloven $\S 53$ en atskillig mer omfattende meny å velge i. Samfunnsstraffen skal gå ut på "samfunnsnyttig tjeneste" - dvs. ulønnet arbeid, "program" eller "andre tiltak som er egnet til å motvirke ny kriminalitet". Det er forutsatt at andelen "samfunnsnyttig tjeneste" ikke skal overskride $75 \%$. Programmene, som den domfelte ikke er pliktig til å delta i, kan både være livsmestringsprogram og kriminalitetsrelaterte - f.eks. ved at de relaterer seg til evnen til å mestre aggressive tilbøyeligheter. "Andre tiltak" vil bl.a. omfatte tilsynssamtaler, og for $\emptyset$ vrig er det omtrent bare fantasien som setter grenser for hva tiltaket kan omfatte. I forarbeidene uttales det imidlertid at "[o]rdinær opplæring i regi av skoleverket faller utenfor". 22 Denne kombinasjonen av disse tre hovedingrediensene innebærer at samfunnsstraffen gir langt større muligheter enn samfunnstjenesten til å skreddersy reaksjonens innhold til den enkelte domfelte.

Et annet fortrinn ved samfunnsstraffen sammenlignet med samfunnstjeneste er at vi ved vilkårsbrudd har fått større muligheter enn tidligere til å unngå omgjøring til ubetinget fengsel. Når vilkårsbruddet ikke består i en ny straffbar handling, er det ikke lenger adgang til straks å begjære omgjøring. Etter straffegjennomføringsloven $\S 58$ må vedkommende først innkalles til en innskjerpingssamtale hvor kriminalomsorgen kan sette nye vilkår. Omgjøring kan først begjæres ved eventuelle nye brudd. Det har vist seg at en del domfelte innser alvoret under denne samtalen og unngår nye brudd.

Samfunnsstraffen erstattet ikke bare samfunnstjenesten. Departementet kom videre til at ordningen med å anvende tilsyn ved betinget dom burde avskaffes. Det viste særlig til følgende uttalelse av Friomsorgsutvalget i NOU 1993: 32 s. 52-53:

${ }^{21}$ Samfunnsstraffen behandles av Matningsdal/Bratholm op.cit. s. 100-190.

${ }^{22}$ Jf. Ot.prp. nr. 5 (2000-2001) s. 172 første spalte. 
"Fastsettelse av vilkår, gjennomføringen av tilsyn og praksis ved brudd på særvilkår i dagens situasjon kan synes tilfeldig, og ivaretar ikke de hensyn til rettslikhet og ensartet praksis som man bør kreve ved en strafferettslig reaksjon. Inngrep i den personlige frihet bør etter utvalgets oppfatning bygge på et sikkert rettslig grunnlag og ha størst mulig ensartet praksis ved gjennomføringen. Utvalget antar at de forslag som fremmes her i forbindelse med tilsyn og andre særvilkår ved betinget dom, vil gi større forutberegnelighet og rettslikhet."

Dette sluttet departementet seg til, og uttalte at som Friomsorgsutvalget hadde man "kommet til at dagens ordning har mange svakheter ikke minst i forhold til likhet og forutberegnelighet". ${ }^{23}$ Departementet kom etter dette til at samfunnsstraffen skulle erstatte betinget dom med tilsyn når "forholdet ligger i $\emptyset$ vre del av anvendelsesområdet for betinget dom". ${ }^{24}$ I stedet for tilsyn åpnet man adgang til å kombinere en betinget dom med meldeplikt for politiet, jf. strl. $§ 53 \mathrm{nr}$. 2, men ved dette fremmøtet skal det ikke gjennomføres noen tilsynssamtale. $^{25}$

Etter min mening er det beklagelig at tilsynsordningen ble avskaffet. Tenker man tilbake på den historiske bakgrunnen for innføringen av betinget dom, var det som kjent det amerikanske probation-systemet som dannet opptakten. Dette elementet kom inn i den norske lovgivningen i 1919, men i 2002 ble det avviklet. Konsekvensen er at domfelte hvis handlinger ikke ligger i grenselandet til ubetinget fengsel, og som dermed faller utenfor anvendelsesområdet for samfunnsstraff, ikke lenger kan få det verdifulle tilbudet som en oppfølgning fra kriminalomsorgen i form av tilsyn og tilsynsprogram kunne gi. Man har rett nok en mulighet for med hjemmel i "generalfullmakten" i Strl. § $53 \mathrm{nr} .3$ å fastsette at den domfelte skal følges opp av kriminalomsorgen. Men när tilsynsordningen er opphevet, er det nok en fare for at denne kompetansen vil bli lite anvendt.

I tillegg uttalte departementet at samfunnsstraffen ville være "en aktuell reaksjon når retten mener det er behov for å ilegge en umiddelbar reaksjon for å minske faren for nye straffbare handlinger, spesielt overfor unge lovbrytere". ${ }^{26}$ Dette utsagnet er begrunnet i en frykt for at dersom man gir en ungdom som viser en faretruende kriminell utvikling flere sjanser i form av betinget dom, kan dette medføre at vedkommende for sent innser alvoret i sin situasjon. I denne sammenheng nevner jeg at vi er tilbakeholden med å anvende ubetinget fengsel overfor barn under 18 år. Av et samlet fangetall på ca. 3.000 personer er ca. ti personer under 18 år, og i november 2003 satt 171 personer under 20 år i fengsel.

\footnotetext{
${ }^{23}$ Ot.prp. nr. 5 (2000-2001) s. 146 annen spalte.

${ }^{24}$ Ot.prp. nr. 5 (2000-2001) s. 176 første spalte.

${ }^{25}$ Ot.prp. nr. 5 (2000-2001) s. 178 annen spalte.

${ }^{26}$ Ot.prp. nr. 5 (2000-2001) s. 176 første spalte.
} 
I 2003 ble det $\mathrm{i}$ alt iverksatt 1.352 dommer på samfunnsstraff samt 81 dommer på samfunnstjeneste. Hovedårsaken til at antallet er forholdsvis lavere enn i Norden for $\emptyset v$ vig, er at det i Norge omtrent ikke anvendes samfunnsstraff ved promillekjøring. For overtredelse av vegtrafikkloven ble det i alt iverksatt 68 dommer som foruten promillekjøring primært gjelder fartsoverskridelse. Tyveri er den viktigste overtredelsen med 311 dommer, deretter følger narkotikaforbrytelser med 294 og legemsfornærmelse og -beskadigelse med totalt 183 dommer.

\section{Promilleprogram}

Selv om vi som nevnt omtrent ikke anvender samfunnsstraff ved promillekjøring, har vi likevel fått en nyskapning på dette området. Med virkning fra 28. juni 1996 er det innført en prøveordning med betinget dom med vilkår om promilleprogram ved promillekjøring, jf. strl. $\S 53 \mathrm{nr}$. 3 bokstav e og $\mathrm{nr}$. 6 og vegtrafikkloven av 18. juni $1965 \mathrm{nr} .4 \S 31$. Forutsetningen er at den domfelte har et alkoholproblem, og at kjøringen kvalifiserer for ubetinget fengsel. For førstegangsovertredere innebærer det at føreren normalt må ha hatt en alkoholkonsentrasjon på over 1,5 promille, mens tidligere domfelte kvalifiserer for ubetinget fengsel også ved lavere alkoholkonsentrasjon, og dermed kan få dom med vilkår om promilleprogram, selv om alkoholkonsentrasjonen er lavere.

Innholdet av promilleprogrammene er regulert ved forskrift fastsatt ved kgl.res. av 28. juni $1996 \mathrm{nr}$. 618. I forarbeidene uttales det at programmene vil kunne bestå av "medisinsk eller psykologisk behandling, undervisning om alkoholens skadevirkninger, konsekvensene av promillekjøring, ofrenes situasjon m.v. og gjøre domfelte bedre skikket til å avholde seg fra promillekjøring" ${ }^{27}$ Alle promilleprogram skal inneholde 20 til 30 timer samtaleorientert undervisning. Videre skal programmet omfatte behandling for alkoholmisbruket. Minstekravet er at den domfelte settes i kontakt med behandlingsapparatet. Den domfelte skal stå under tilsyn av kriminalomsorgen i ett år dersom ikke retten uttrykkelig har fastsatt noe annet.

Det finnes ikke eksakte opplysninger om hvor stor andel av promillekjørerne som idømmes denne reaksjonen, og som ellers ville ha blitt idømt ubetinget fengsel ved kjøring påvirket av alkohol. Men et anslag på 25 til $30 \%$ er antakelig relativt nær det faktiske forhold. ${ }^{28}$

\footnotetext{
${ }^{27}$ Ot.prp. nr. 43 (1994-95) s. 11.

${ }^{28}$ Se Matningsdal/Bratholm op.cit. s. 480 hvor det fremgår at i Rogaland utgjorde andelen 48,03 $52,53-36,84-34,18$ og 28,28 \% i årene 1997 til 2001. Tilsvarende, detaljerte registreringer har vi ikke i de andre fylkene.
} 


\section{Konfliktråd}

Ordningen med mekling i konfliktråd bør også nevnes. Etter flere års utprøving ble ordningen lovfestet ved lov av 15. mars $1991 \mathrm{nr}$. 3. Alle kommuner skal ha konfliktråd. Konfliktrådets oppgave er "å megle i tvister som oppstår på grunn av at en eller flere personer har påført andre en skade, et tap eller en annen krenkelse”. Antall sivile saker har vært noe høyere enn antall straffesaker som i årene 2000 til 2002 utgjorde henholdsvis 2.840, 2.922 og 2.174 saker.

Et sentralt mål med konfliktrådordningen er å bringe gjerningsperson og offer raskt sammen slik at de ved meklerens hjelp kan avtale hvordan saken skal løses. For å oppnå dette kan politiet oversende saken til konfliktrådet selv om tiltalespørsmålet hører under høyere påtalemyndighet, jf. strpl. § 67 fjerde ledd. I enkelte kommuner er det endatil innført en prøveordning som gir lensmannen kompetanse til å treffe beslutning om slik overføring i nærmere bestemte saker.

Mekling i konfliktråd krever partenes samtykke, jf. strpl. § 71 a. Overføring stenger for videre straffeforfølgning, og dersom saken avsluttes med en avtale, kan påtalemyndigheten bare åpne ny straffeforfølgning dersom den siktede bryter avtalen "vesentlig", jf. konfliktrådloven $\S 16$.

\section{Utvidet inndragning}

Mht. $\varnothing$ konomiske reaksjoner kan det særlig nevnes at Norge ved lov av 11. juni 1999 nr. 39 i strl. $§ 34$ a fikk tilføyd en ny bestemmelse om utvidet inndragning. Bestemmelsen krever at lovovertrederen finnes skyldig i en straffbar handling "av en slik art at den kan gi betydelig utbytte", og at vedkommende på grunnlag av ordinære beviskrav finnes skyldig i en eller flere straffbare handlinger som kan medføre straff av fengsel i seks år eller mer. Ved gjentakelse reduseres kravet til strafferammen noe. Er dette vilkåret oppfylt, kan alle formuesgoder som tilhører lovovertrederen inndras dersom han "ikke sannsynliggjør at formuesgodene er ervervet på lovlig måte”. Det er tilstrekkelig at lovovertrederen fremskaffer sannsynlighetsovervekt for lovlig erverv. ${ }^{29}$

\section{Utviklingen videre}

I de kommende årene vil vi nok ved enkelte overtredelser fortsatt oppleve et press i retning av å anvende strengere reaksjoner. Endringene av strl. §§ 61 og 62 med sikte på strengere straff ved gjentakelse og konkurrens, som er omtalt i punkt I, vil stå sentralt i denne sammenheng.

Men samtidig vil det være en sentral oppgave å videreutvikle reaksjoner i frihet. I denne sammenheng viser jeg til at det i Stortingsmelding nr. 27 (1997-

\footnotetext{
${ }^{29}$ Bestemmelsen er behandlet i Rt. 2003 s. 897 og 2003 s. 1096. En fremstilling av den er gitt i Bratholm/Matningsdal op.cit. s. 241-257.
} 
98) Om kriminalomsorgen s. 7 uttales at det er "en ønsket kriminalpolitisk utvikling at man $\emptyset$ ker anvendelsen av samfunnsstraffer og knytter fengselsstraffen til den grovere kriminaliteten". Dette $\emptyset$ nsket vil sannsynligvis etter hvert medføre at nedre grense for bruk av ubetinget fengsel vil bli høyere ved en del lovovertredelser, ${ }^{30}$ og at man dessuten i en viss utstrekning anvender reaksjoner i frihet ved mindre grove overtredelser av straffebud som det i dag stort sett anvendes ubetinget fengsel for.

Endelig nevner jeg at da mange domfelte er tunge rusmisbrukere, er det nå nedsatt en arbeidsgruppe med tidsfrist 1 . august 2004 som skal utrede et eventuelt prøveprosjekt i Norge av ordningen med Drug Court som man har i enkelte land. Målgruppen skal være personer med narkotikarelatert kriminalitet.

Adresse:

Høyesterett

Postboks 8016 Dep

$\mathrm{N}-0030$ Oslo

magnus.matningsdal@hoyesterett.no

\footnotetext{
${ }^{30}$ Se i denne sammenheng det prinsipielle utsagnet i Rt. 2002 s. 1403 om bruk av samfunnsstraff ved trygdebedrageri.
} 